\title{
EPHA7 wt Allele
}

National Cancer Institute

\section{Source}

National Cancer Institute. EPHA7 wt Allele. NCI Thesaurus. Code C111843.

Human EPHA7 wild-type allele is located in the vicinity of $6 q 16.1$ and is approximately 180 $\mathrm{kb}$ in length. This allele, which encodes ephrin type-A receptor 7 protein, is involved in regulation of developmental processes. 